\title{
解説
}

\section{JT-60 真空容器壁の建設段階の清浄化処理*}

山本 正弘**. 中村 博雄 ${ }^{* *}$. 清水 正亜 ${ }^{* *}$. 荻原 徳男**

新井 貴 $* *$. 高津 英幸 ${ }^{* *} \cdot$ 能代谷 彰二**.大都 和良 $* *$

原 泰博 $* * *$. 森田 隆昌 $* * * *$. 笹島 強 $* * * *$. 大和田 公郎 $* * * *$

高橋 昇竜 $* * * * \cdot$ 根本 文夫****

(昭和 60 年 6 月 3 日受理)

\author{
Surface Cleaning of JT-60 Vacuum Vessel during a Construction* \\ Masahiro YAMAMOTO**, Hiroo NAKAMURA**, Masatsugu SHIMIZU**, \\ Norio OGIWARA**, Takashi ARAI**, Hideyuki TAKATSU**. \\ Shoji NOSHIROYA**, Kazuyoshi OHTSU**, Yasuhiro HARA***, \\ Takamasa MORITA****, Hiroshi SASAJIMA****, Kouro OWADA****, \\ Shoryu TAKAHASHI**** and Fumio NEMOTO**** \\ **(JAERI, Naka Fusion Research Establishment, Naka-machi, Ibaraki) \\ ***(on leave from ULVAC Corporation, Chigasaki, Kanagawa) \\ ****(Hitachi Works, Hitachi Co. Ltd, Hitachi, Ibaraki)
}

(Received June 3, 1985)

\section{1.はじめに}

原研が建設を進めていた臨界プラズマ試験装置（略称 JT-60）は，昭和60年の 3 月下旬に完成し，4月 8 日プ ラズマの点火に成功した．現在は加熱装置等の据付が進 められている.

JT-60 本体真空容器の真空性能の仕様值は, プラズマ の物理的条件から非常に厳しい值が設定されている.こ こでは, その性能達成のために実施した JT-60 真空容 器内部の, 工場製作から現地据付完了迄の清浄化処理に ついて述べる.

\section{2. $\mathrm{JT}-60$ 本体の概要}

JT-60 本体の鳥㒈図及び主な諸元を図 1 及び表 1 に示

* 昭和 60 年 2 月 15 日 $\quad$ 日本真空協会 2 月研究会で講演

** 日本原子力研究所那珂研究所 (茨城県那珂郡那珂町)

*** 日本真空技術懒（神奈川県茅崎市）

**** (浰日立製作所 日立工場（茨城県日立市）
す. また, 真空性能仕様值を表 2 に示す. JT-60本体 は, プラズマの発生, 閉じ边めを行なうものであり, 真 空容器, トロイダル磁場コイル, ポロイダル磁場コイ ル, 架台, 真空排気設備, 本体一次冷却設備, 本体制御 設備, 可動リミタ及び半固定リミタ等から構成される.

真空容器はインコネル625製の厚肉リングとベローズ をトロイダル方向に交互に配列した主半径が約 $3 \mathrm{~m}$ の トーラス状の容器で, ポロイダル断面の形状は, 内側の 短径が約 $2 \mathrm{~m}$, 長径が約 $3 \mathrm{~m}$ の卵形である. 真空容器の 内部には，プラズマ不純物対策のための磁気リミタコイ ルが 3 本設置されており，これらは，インコネル625製 の保護管に収納されている.

真空容器の内壁及び磁気リミタコイル保護管の外壁 は，純モリブデン及びインコネル625製の第一壁（ライ ナ, 固定リミタ, 磁気リミタ板及びリップルロス熱負荷 保護板等から成る）で覆われており，第一壁の表面は， プラズマの不純物対策のため総て $20 \mu \mathrm{m}$ の炭化チタン で被覆されている. 真空容器のポロイダル断面の構造を 


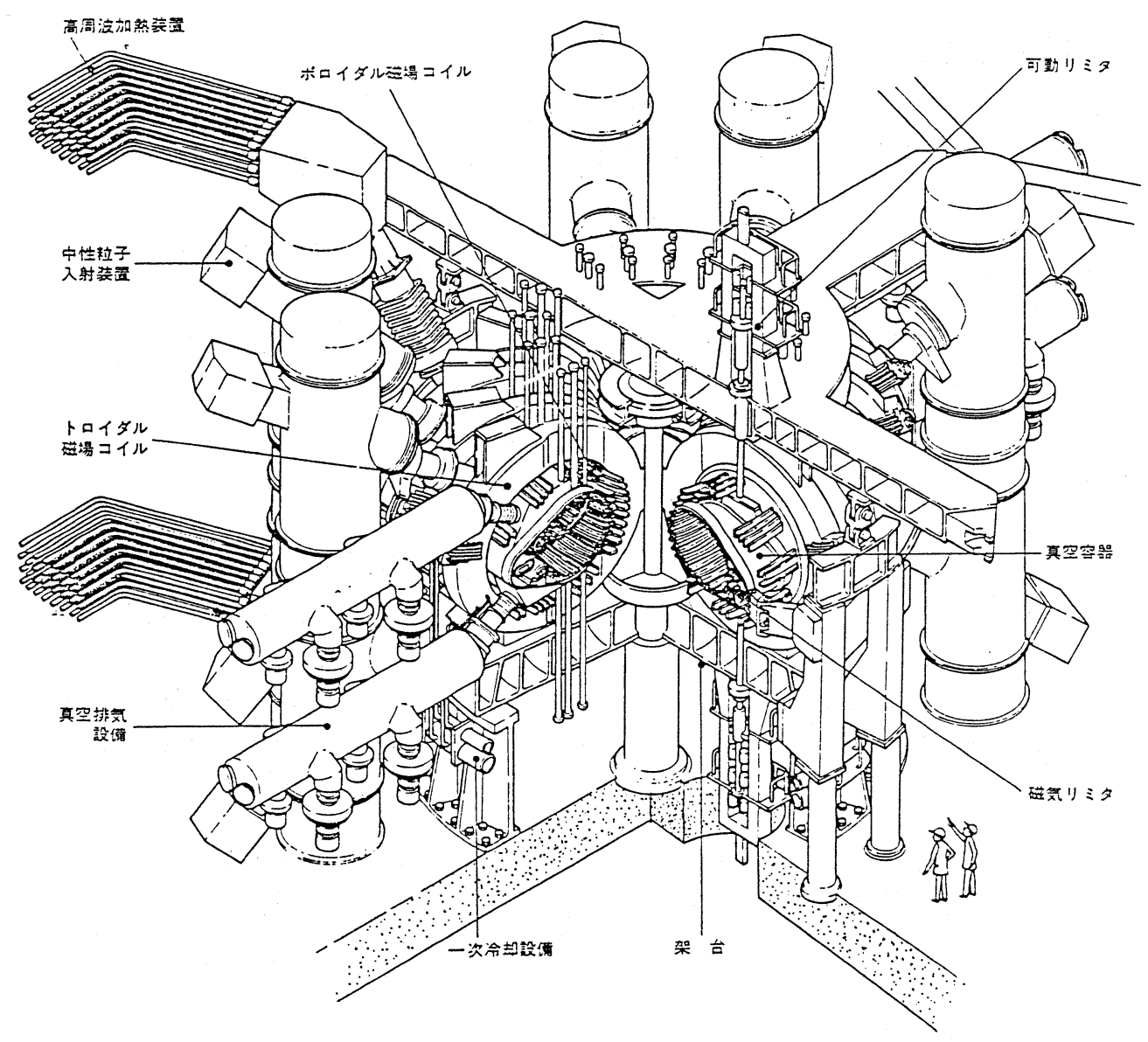

図 $1 \mathrm{JT}-60$ 本体鳥㒈図

表 1 JT-60 の諸元

\begin{tabular}{|c|c|c|}
\hline 項 & & 数 \\
\hline トーラス半径（主半径） & $\mathrm{R}(\mathrm{m})$ & 3.0 \\
\hline 断面半径（副半径） & $\mathrm{a}(\mathrm{m})$ & 0.95 \\
\hline アスペクト比 & $\mathrm{R} / \mathrm{a}$ & 3.16 \\
\hline トロイダル磁場 & $(\mathrm{T})$ & 4.5 \\
\hline プラズマ電流 & (MA) & 2.7 \\
\hline
\end{tabular}

図 2 に示す.

また, 真空容器には各種ポート及びメタルシールゲー トバルブ等が設置され，ポートを含む真空容器全体の外 表面は温度制御装置で覆われている.

以上述べたように, 真空容器の内部に多くの部品が取 り付くため, 真空容器の見かけの表面積は $150 \mathrm{~m}^{2}$ であ るが, 真空に面する部分の真の表面積は $2,750 \mathrm{~m}^{2}$ に達す

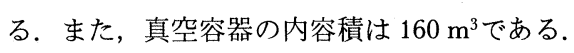

表 2 JT-60 真空容器の真空に関する性能

\begin{tabular}{l|l}
\hline \hline 許容放出ガス量 & $1.33 \times 10^{-8} \mathrm{~Pa} \cdot \mathrm{m}^{3} / \mathrm{sec} \cdot \mathrm{m}^{2}$ \\
\hline 許容総リーク量 & $6.65 \times 10^{-8} \mathrm{~Pa} \cdot \mathrm{m}^{3} / \mathrm{sec}$ \\
\hline 真 空 圧 カ & $1.33 \times 10^{-6} \mathrm{~Pa}$ \\
\hline
\end{tabular}

真空容器は組立及び輸送の都合上工場においてトロイ ダル方向に 2 分割して製作し現地において溶接により接 続した。なお, トロイダル磁場コイルの組立及びポロイ ダル磁場コイルの溶接接続は, この分割部を利用して行 なった。これらの作業は真空管理上影響の大きいもので あった。

\section{3. 真空容器壁の清浄化処理方法}

\section{1 工場製作時の清净化処理方法}

真空容器は, 工場で180度セクタに 2 分割して製作し, その時の清浄化処理方法は, 次の 3 つに大別して実施し 


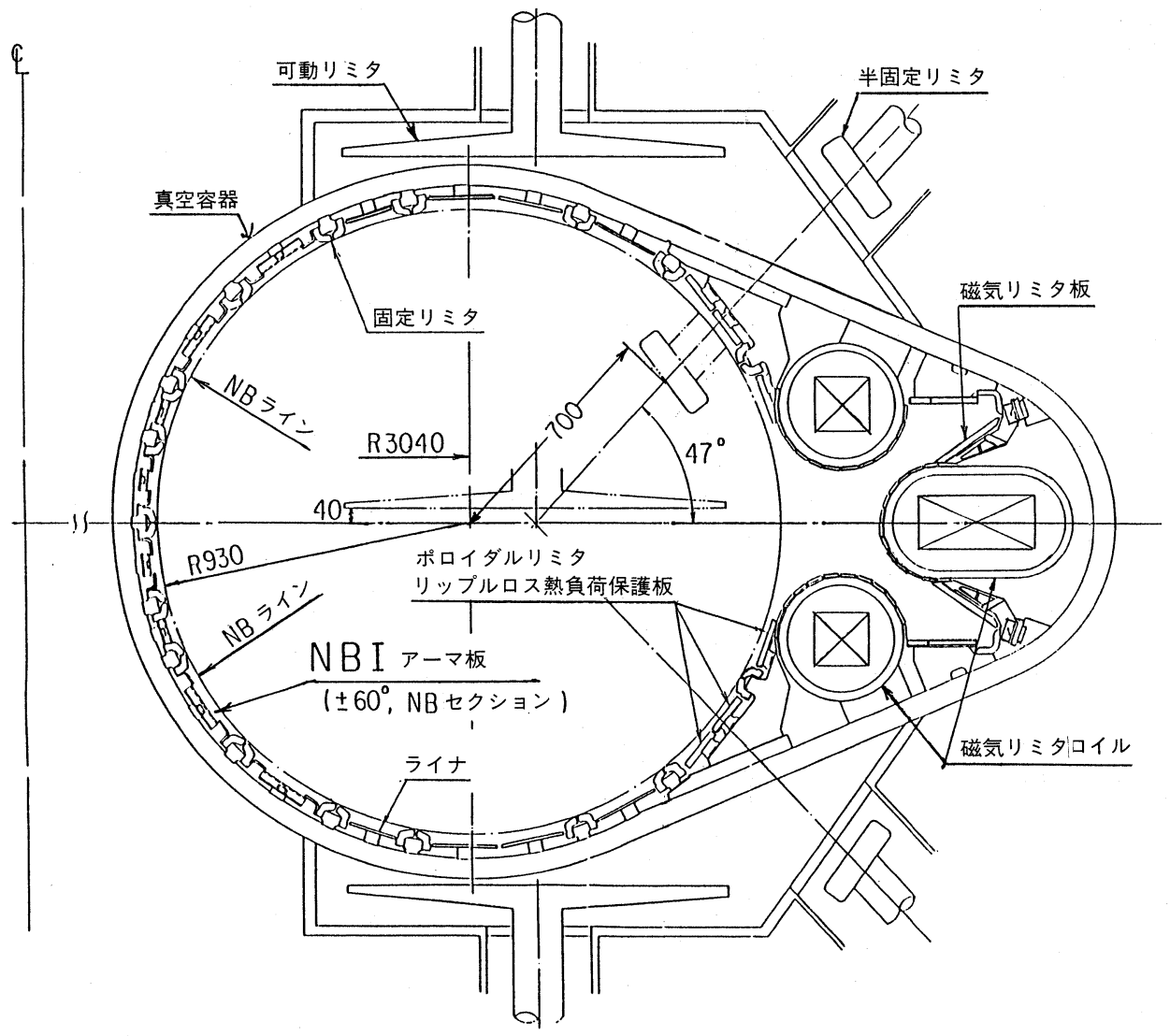

図 2 真空容器の断面図

た.

(1) 真空容器に溶接又は機械的に取り付けられる部品 の清浄化処理方法

（2）組立過程の清浄化処理方法

(3) 真空容器内における作業者及び工具類に対する防 塺管理

(1)の部品製作段階の清净化処理は, 真空容器へ取り付 けた後でフレオン洗浄を行なうもの, セラミックス等加 工々程で油污れしないもの, 機械加工品等加工々程で油 污れのするものの 3 種類に分けてアセトンの拭き取りに よる荒脱脂，アセトン洗浄，フレオン洗浄を適宜組合せ て行なった。

(2)の組立過程の清浄化処理方法を以下に述べる.

清浄化処理は，厚肉リングとベローズの接続溶接を行 なって 180 度セクタの真空容器が完成した段階と内部に 機械的に取り付けられる部品の組立を終了した段階の 2 回行なった.

この段階で真空リーク試験を行なうため真空排気と $500^{\circ} \mathrm{C}$ ベーキングを実施した，次に，真空容器内を再び 大気に戻して, 磁気リミタコイルを真空容器の中に組込 み, その後 3 回目の清净化処理を実施した. 再び, 真空 排気とベーキングを実施後, リーク試験を実施し工場に おける製作を完了した。

なお, 工場の清净化処理方法は, 清掃, アセトン及び フレオンの拭きとり洗浄並びにフレオンのジェットスプ レー洗浄を組合せて実施した。フレオンのジェットスプ レー洗浄作業は, 図 3 に示すようにエアーラインスーツ を着用して行なった。

(3)の真空容器内作業の作業者及び工具類に対する防塵 管理は，塵埃が真空容器に侵入するのを極力抑えること に主眼をおき次のような対策をした。

作業者の身体，頭，手及び足に防鹿用の服，白帽，手 袋及び足袋を着用し，また，治工具類については，外表 面をフレオンで拭き取り洗浄を行なったほか, 照明や溶 接器具などのリード線の表面をテフロンテープなどで覆 った. 


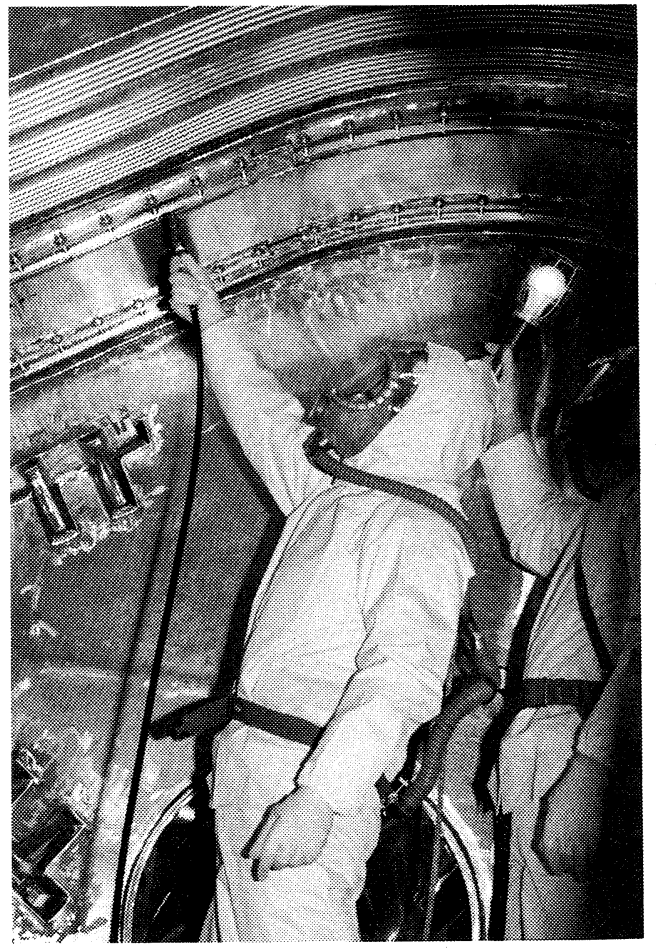

図 3 フレオンスプレー洗浄

\section{2 現地据付時の清浄化処理}

原研那珂研究所に搬入された 180 度セクタ 2 分割の真 空容器はJT-60 本体を構成する前述の他の主要機器と 併行に組立作業を実施した。 また, 真空容器内に設置さ れる第一壁, プラズマ位置制御用の電磁気計測検出器等 も他の作業と併行に組立作業を実施した。

本来, 真空容器内に取り付く機器は, 2 分割された真 空容器が 1 つの容器に接続された状態で, 組立作業を行 なうことが防塵等の観点から望ましい，しかし，JT-60 の組立と工程短縮を考慮し 2 箇所の接続部のうち 1 箇所 が開口した状態で, 容器内機器の組立を実施した。

このような現地据付時における真空容器の清浄化処理 の問題点をまとめると次のとおりである.

(1) 現地で真空容器内に組立なければならない部品, 機器が非常に多いので, 工場で清浄化処理しても再 び污れてしまう可能性が高い.

(2) 他の大型機器と併行して組立を実施しなければな らないので, 長い期間真空容器内の防塵対策が満足 にできない

(3) 真空容器内で実施する種々の溶接作業は, 真空容 器内を污す大きな原因になる.

（4）JT-60 本体の組立室（本体組立室）で，大型車両
の出入及び大型クレーンの稼動が頻繁に行なわれ るため, 本体組立室への塵埃の持込み，侵入が著 しく, 真空容器内が污れ易い.

(5) 現地の据付け期間が約 2 年にも及ぶため, 真空容

器は塵埃の多い環境に曝される期間が長い。

など，質の良い清净な真空を要求される核融合装置の 真空容器の組立にとって非常に条件が悪い.

このような環境下における, 真空容器内機器の現地組 立工程と清浄化処理工程の概要を以下に述べる.

溶接, 部品の合せ加工, 治工具類の撒去作業等, 真空 容器を污し易い作業を行ない, 真空容器内の 1 回目の洗 浄を実施した。次に，第一壁以外の機械的に取付られる 機器類の取付作業を行ない, 2 回目の真空容器内洗浄を 実施した。 その後，第一壁の取付作業，上側ポートゲー トバルブの取付, 真空容器接続部の残り 1 箇所の溶接作 業を終了後 3 回目最後の真空容器内洗浄を実施した. こ こで, 一旦, 真空容器内を真空排気して, ベーキング試 験とリーク試験を行ないベーキング装置の性能と真空容 器の健全性の確認を行なった. 再度, 真空容器内を大気 に戻して, 下側ポートゲートバルブの取付等, 残りの組 立作業終了後, ベーキングと最終的な真空リーク試験を 実施し真空容器の組立を完了した。

各工程の洗浄後の検査は, 目視による検査の他, アセ トンを浸潤させた特殊ガーゼで, 真空容器内部の任意の 場所を隈なく拭き，ガーゼが污れないことを判定条件と した検査を実施し清浄度を確認した。

次に, 各作業の内容の詳細について述べる.

真空容器内の洗浄は, 真空掃除機に依る清掃, エアー ブロー, 温水の吹き付け洗浄，フレオンの吹き付け洗浄 及びフレオン又はアセトンの拭きとり洗浄等の一連の作 業によった。

次に, 真空容器内への塵埃侵入防止対策方法について 述べる.

真空容器のポートのフランジ及びゲートバルブは, 総 てメタルシール構造なので，シール部に塵埃が付着する と, 真空リークの原因となる, そのため, 質の良い真空 を得るためにも, 極力, 真空容器内に塵埃が侵入するの を防止する必要がある.

その対策として，(1)真空容器内への作業者の出入り用 マンホールに直結して, ビニール等で仕切られた部屋を 設け, そこで, 真空容器内一の持ち込み治工具及び部品 の洗浄並びに作業服や靴の着替を行なった. (2)ゲートバ ルブの取り付けに際して, ビニール製のクリーンルーム を設置した。(3)真空容器の上側ポートからエアーフィル 夕 $(0.3 \mu \mathrm{m}$ 以上のダストを $99.9 \%$ 除去可能 $)$ を通して 清浄な空気を真空容器内に供給し，その内部を陽圧にし 
表 3 真空容器内等の浮遊ダスト粒子数

（大きさ $0.5 \mu \mathrm{m}$ 以上）個 $/ \mathrm{ft}^{3}$

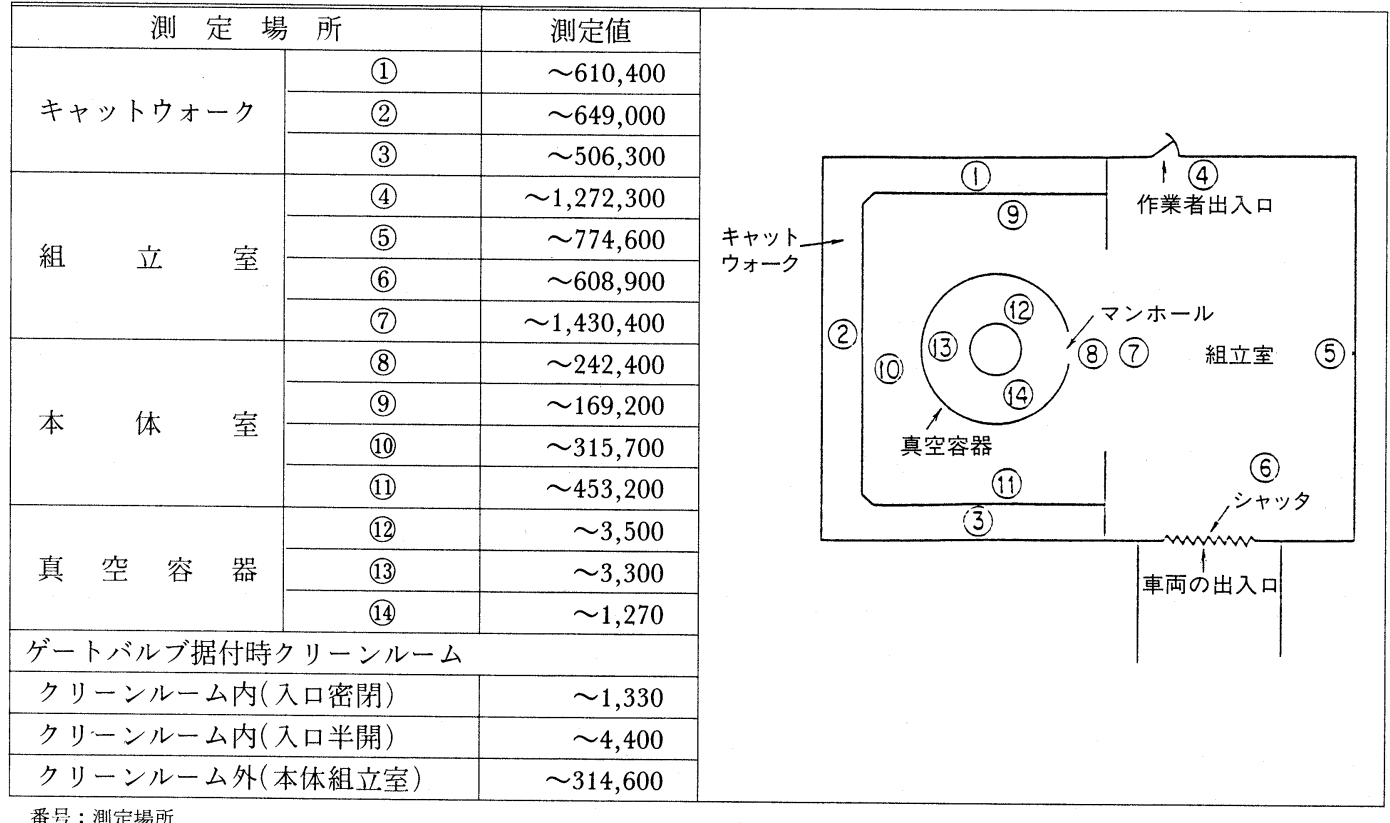

番号: 測定場所

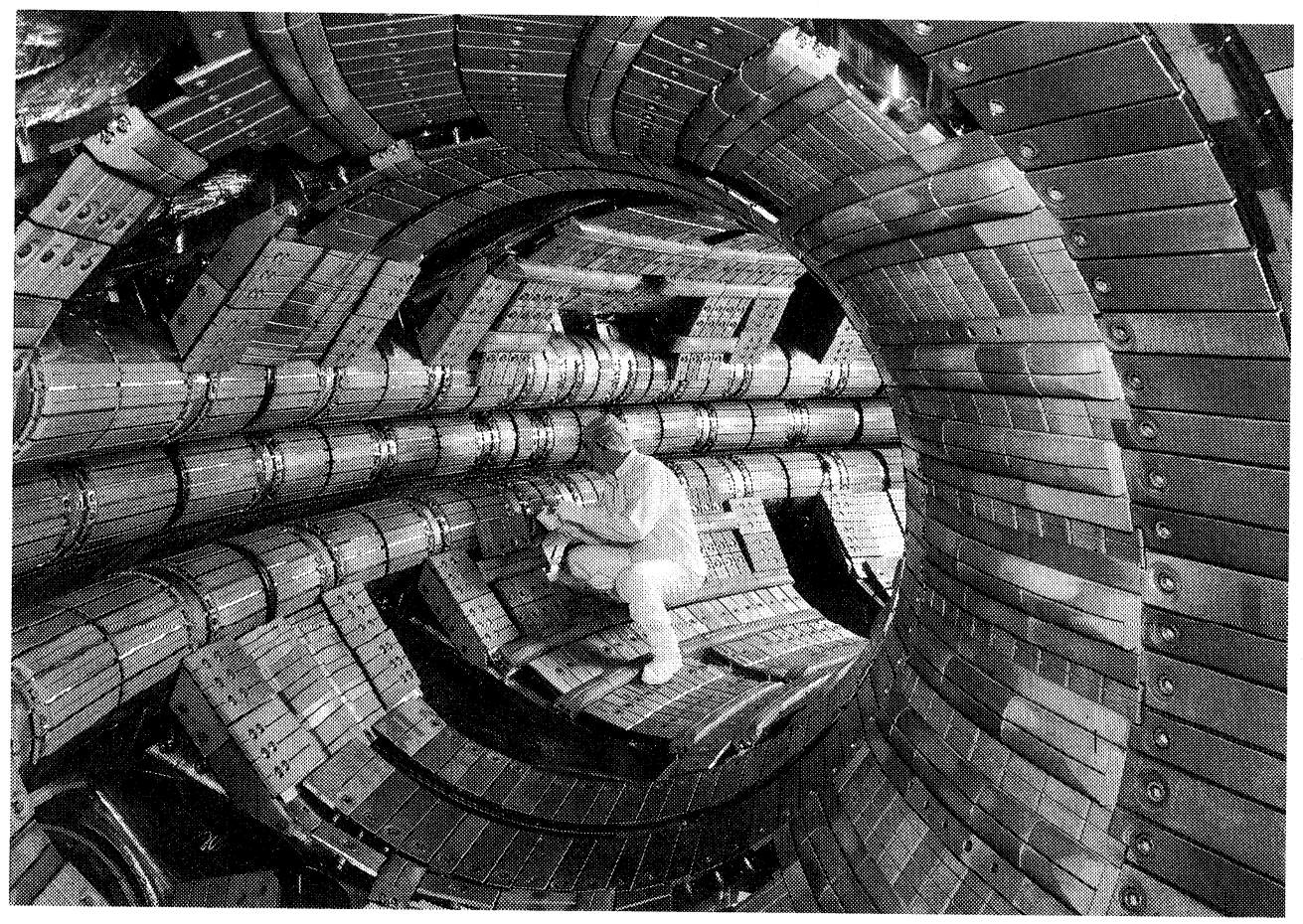

図 4 最終洗浄後の真空容器内部 
表 4 放出ガス速度及び真空圧力

\begin{tabular}{|c|c|c|c|}
\hline & 日 付 & 真空圧力 $\mathrm{P}_{\mathrm{a}}$ & $\mathrm{q} \mathrm{P}_{\mathrm{a}} \mathrm{m}^{3} / \mathrm{s} \cdot \mathrm{m}^{2}$ \\
\hline $\begin{array}{c}1 \text { ベーキング前 } \\
(1 \text { 回目 })\end{array}$ & 10月20日 & $2.2 \times 10^{-4}$ & $1.9 \times 10^{-8}$ \\
\hline $\begin{array}{c}2 \text { ベーキング後 } \\
(1 \text { 回目 })\end{array}$ & 10月26日 & $6.2 \times 10^{-6}$ & $2.1 \times 10^{-8}$ \\
\hline $\begin{array}{l}3 \text { 真空リーク補 } \\
\text { 修 }\end{array}$ & 10月30日 & $2.2 \times 10^{-5}$ & $6.9 \times 10^{-9}$ \\
\hline $\begin{array}{c}4 \text { ベーキング前 } \\
\text { (2 } 2 \text { 回目) }\end{array}$ & 11月19日 & $1.5 \times 10^{-5}$ & $7.1 \times 10^{-9}$ \\
\hline $\begin{array}{c}5 \text { ベーキング後 } \\
(2 \text { 回目) }\end{array}$ & 11月26日 & $8.5 \times 10^{-6}$ & $2.4 \times 10^{-9}$ \\
\hline $\begin{array}{c}6 \text { コイル通電試 } \\
\text { 験中 }\end{array}$ & 12 月 21 日 & $1.3 \times 10^{-6}$ & $8.5 \times 10^{-10}$ \\
\hline $\begin{array}{c}7 \text { 高温時コイル } \\
\text { 通電試験前 }\end{array}$ & 2 月 13 日 & $5.9 \times 10^{-6}$ & $5.3 \times 10^{-9}$ \\
\hline $\begin{array}{c}8 \text { 高温時コイル } \\
\text { 通試験後 }\end{array}$ & 2 月 25 日 & $9.7 \times 10^{-7}$ & $1.5 \times 10^{-9}$ \\
\hline $9 \quad \prime \prime$ & 2 月 27 日 & $8.3 \times 10^{-7}$ & $7.6 \times 10^{-10}$ \\
\hline 10 & 2 月28日 & $7.4 \times 10^{-7}$ & $6.8 \times 10^{-10}$ \\
\hline
\end{tabular}

てマンホール等の開口部からの塵埃の侵入防止をした。 同時に作業者に対する酸素欠乏防止対策を行なった。(4) 本体組立室, 真空容器内及びクリーンルーム内につい て，塵埃の浮遊ダスト粒子数をパーティクルカウンタに より適宣測定し（表 3 参照）, 清浄度を確認しながら作 業を進めた。(5)本体組立室及び真空容器内の定期的な清 浄, 機器 ·資材等の搬入用大型車両の本体組立室入入る 際の洗車並びに作業者の防塵服や靴の底のクリーニング， などを定常的に実施した.

最終的洗浄後の真空容器内部を図 4 に示す.

\section{4. 真空特性}

真空圧力及び放出ガス速度のデータを表 4 に示す. このデータは 1 回目のベーキング前から, 高温時のコ イル通電試験終了時までの一連の試験中のデータであ る.

なお，本試験のベーキング中，取り合いフランジ部に 真空リークを生じたがボルトの増し締めを行なって補修 した.

(1)真空圧力 : 1 回目のベーキング後では, 仕様を満足 しなかったが 2 回目のベーキング後，1 カ月経過して， 仕様を満足した.

放出ガス速度 : 1 回目のベーキング前で, ほぼ仕様を 満足しており, 真空容器内の清浄度は非常に良かったと 思われる.リーク補修後は仕様を十分満足した。

なお，測定方法はビルドアップ法に依って行なった. 具体的には真空排気設備のターボ分子ポンプの上流にあ るゲートバルブを一斉に閉じて, 単位時間当たりの真空 圧力の上昇を測定して求めた.

(3)質量分析 : 真空容器のベーキング開始前の質量分析

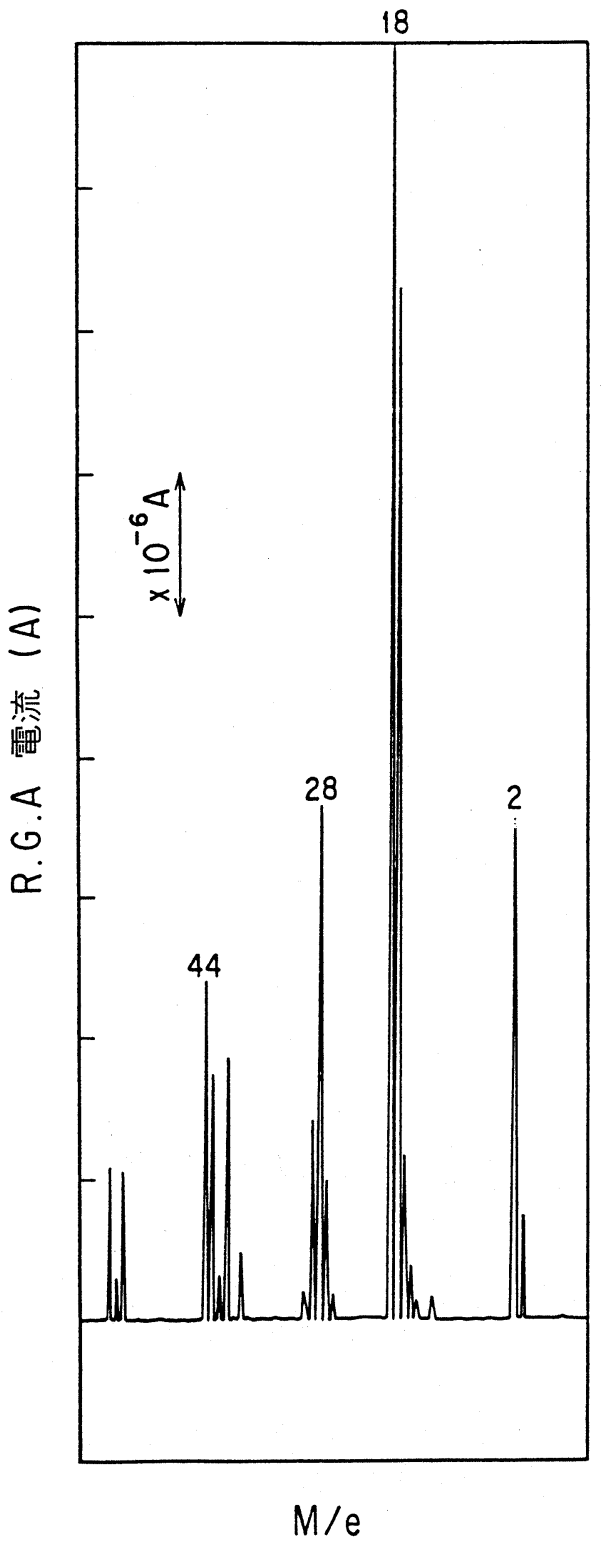

図 5 真空谷器ベーキング開始前の質量分析結果

結果（図 5 参照）では，ハイドロカーボン系のマスピー クは比較的小さく，洗浄程度は良好であったと言える. また，ベーキング後の質量分析結果では水素が支配的で あり，ハイドロカーボン系はほとんど見られなかった。

\section{5. まとめ}

JT-60 真空容器の清浄化処理の結果, 得られた成果を まとめると次のとおりである.

(1) 真空容器が大型で極めて複雑な構造にも係わらず JT-60 の真空仕様の真空王力及び放出ガス速度を十 
分満足する性能が得られた。

(2) ゲートバルブ及びフランジのシール部は，塵埃の 啮み込に依る真空リークはなく，ダス卜管理の成果 が十分にあった。この結果, ダストの管理値 $1 \times$ $10^{4}$ 個 $/ \mathrm{ft}^{3}$ は適当であったと思われる.

(3) 現地組立完了後の真空容器のベーキング開始前の 質量分析結果では, 八イドロカーボン系のマスピー クは比較的小さく, 洗浄程度は良好であったと言え る.

（4）昭和60年 4 月から 3 カ月間のプラズマ放電実験で は, 再現性の良いプラズマ生成の実験結果が得られ ており, 真空容器内の清浄度が良かった証拠の $1 つ$ と言える.

\section{謝 辞}

本 JT-60 真空容器壁の清浄化処理は, 原研, 俶日立 製作所の 2 者の協力のもとに実施された。この間, 太田 充 JT-60 第 2 試験室長, 大久保実同室開発グループリ 一ダをはじめ, 第 2 試験室の多くの方々から有益な御意 見，御指導を戴いた。

また, 吉川允二臨界プラズマ研究部長, 飯島勉 JT60 試験部長, 田村早苗臨界プラズマ研究部次長, に終 始，激励をいただいた。

以上の方々と実施に当たられた㑣日立製作所の関係諸 氏に深く感謝致します。 